Wardani, et al/Jurnal Ekonomi Syariah Teori dan Terapan Vol. 6 No. 7 Juli 2019: 1450-1461;

KESEJAHTERAAN PETANI PENGGARAP SAWAH PADA PENERAPAN AKAD MUZARA'AH DENGAN

PENDEKATAN MAQASHID SYARI'AH DI TULUNGAGUNG

\title{
KESEJAHTERAAN PETANI PENGGARAP SAWAH PADA PENERAPAN AKAD MUZARA'AH DENGAN PENDEKATAN MAQASHID SYARI'AH DI TULUNGAGUNG ${ }^{1}$
}

\author{
Dias Rizqi Wardani \\ Departemen Ekonomi Syariah-Fakultas Ekonomi dan Bisnis-Universitas Airlangga \\ Email:wardani.dias@gmail.com \\ Siti Inayatul Faizah \\ Departemen Ekonomi Syariah-Fakultas Ekonomi dan Bisnis-Universitas Airlangga \\ Email: siti-i-f@feb.unair.ac.id
}

\begin{abstract}
:
Muzara'ah is the contract between farm workers and farm owners in which, cost of cultivations, seeds, and fertilizers are provided by the farm owners, meanwhile the farm workers have responsibility in giving their best efforts on cultivating the farmland. Later then, the harvest will be shared according to the contract that has been agreed. The purpose of this research is to describe farmer's welfare in the village of Sodo after implementing Muzara'ah Contract with the Maqashid Sharia approach. This research approach is qualitative descriptive and uses case study as its strategy. Informants in this research are administrator from Krido Tani Farmers Association, The farm workers, and the farm owners. These informants determined by using purposive sampling technique. The data collection techniques are carried out through interview and direct observation. According to the research, it was shown that agricultural cooperation with Muzara'ah Contract has a role in improving farm workers' welfare, viewed from the indicators of Maqasid Sharia.
\end{abstract}

Keywords : Muzara'ah, Welfare, Farmer, Agricultural Cooperation

\section{PENDAHULUAN}

Konsep kesejahteraan dalam islam dibahas dalam kajian Maqashid Syari'ah yang dapat diukur dari tercapainya kebutuhan Agama (Ad-Dien), jiwa (AnNafs), akal (Al-Aql), keturunan (An-Nasl), dan harta (Al-Maal). Dalam mencapai kesejahteraan yang diinginkan, manusia melakukan berbagai kegiatan dimana dalam Islam berbagai kegiatan tersebut diatur dalam bidang muamalah. Dalam rangka mencapai kesejahteraan, manusia diperbolehkan bahkan dianjurkan untuk saling bekerjasama. Salah satu bentuk kerjasama yang dapat dilakukan adalah kerjasama dalam bidang pertanian yaitu kerjasama pengelolaan lahan pertanian antara pemilik lahan dengan petani penggarap. Dimana nantinya hasil dari kerjasama tersebut dibagi sesuai dengan kesepakatan yang telah disepakati sebelumnya. Islam menaruh perhatian yang besar terhadap kegiatan pertanian dan cabangnya. Perhatian tersebut terlihat dari banyaknya ayat Alqur'an dan Hadist serta kehidupan Rasulullah SAW dan para sahabatnya yang berkaitan dengan pertanian. Terdapat tiga sistem kerjasama pertanian yang ada dalam islam yaitu: Musaqah, Mukhabarah, dan Muzara'ah. . Sistem Muzara'ah, adalah kerjasama antara pemilik sawah dengan petani penggarap. Biaya, benih, serta pupuk berasal dari pihak pemilik sawah

\footnotetext{
${ }^{1}$ Jurnal ini merupakan bagian dari skripsi Dias Rizqi Wardani, NIM: 041211431169 , yang diuji pada tanggal 15 April 2019.
} 
Wardani, et al/Jurnal Ekonomi Syariah Teori dan Terapan Vol. 6 No. 7 Juli 2019: 1450-1461; KESEJAHTERAAN PETANI PENGGARAP SAWAH PADA PENERAPAN AKAD MUZARA'AH DENGAN PENDEKATAN MAQASHID SYARI'AH DI TULUNGAGUNG

sedangkan petani penggarap sawah bermodalkan tenaga serta kemampuan untuk mengolah sawah saja. Nantinya hasil panen akan dibagi menurut kesepakatan bersama. Kerjasama dalam bidang pertanian yaitu Muzara'ah ini juga diterapkan oleh masyarakat Desa Sodo Kecamatan Pakel Kabupaten Tulungagung. Berdasarkan data yang diperoleh dari pemerintah Desa Sodo Kecamatan Pakel Kabupaten Tulugagung, Desa Sodo merupakan wilayah yang berada di Selatan kota Tulungagung, berjarak sekitar $25 \mathrm{Km}$ dari pusat kota Tulungagung. Desa ini memiliki total wilayah seluas $172 \mathrm{Ha}$ dengan lahan sawah selvas $109 \mathrm{Ha}$. Desa Sodo memiliki satu kelompok tani yaitu kelompok tani Krido Tani yang dibentuk oleh masyarakat desa setempat. Kelompok tani ini didirikan dengan tujuan agar para petani memiliki wadah untuk saling berkoordinasi antar petani lainnya. Wadah berkumpulnya segenap petani yang masih belum maksimal dalam mengolah lahan pertaniannya sehingga belum mencapai hasil produksi sesuai dengan harapan pemerintah, sekaligus sebagai upaya membantu pemerintah dalam mengentaskan kemiskinan, dan menekan angka pengangguran khususnya di Desa Sodo dan sekitarnya. Terdapat beberapa program yang dimiliki oleh kelompok tani Krido Tani ini, salah satunya adalah program pemberdayaan anggota. Dalam program ini kelompok tani berperan sebagai mediator, yaitu mediator yang mempertemukan petani pemilik sawah dengan petani penggarap sawah yang kemudian melakukan kerjasama dalam bidang pertanian dengan menggunakan akad muzara'ah. Program ini dibuat untuk membantu petani penggarap sawah mendapatkan pekerjaan yang lebih menentu daripada biasanya yang hanya sebagai buruh tani serabutan, dengan kerjasama muzara'ah ini petani penggarap sawah memperoleh penghasilan yang lebih baik dari biasanya sehingga dapat memberikan nafkah bagi kelangsungan hidup keluarganya yang akhirnya dapat mencapai kesejahteraan. Dari sinilah penulis tertarik untuk menulusuri dan meneliti tentang penerapan akad muzara'ah yang terjadi di Desa Sodo Kecamatan Pakel Kabupaten Tulungagung. Berdasarkan latar belakang diatas, penulis berusaha mengetahui dan menganalisa bagaimana kesejahteraan petani penggarap sawah setelah menerapkan akad muzara'ah. Oleh karena itu dalam penelitian skripsi ini diambil judul "Analisis Kesejahteraan Petani Penggarap Sawah Pada Penerapan Akad Muzara'ah di Desa Sodo Kecamatan Pakel Kabupaten Tulungagung dengan Pendekatan Maqashid Syari'ah".

II. LANDASAN TEORI

Heryawan (2009) menyatakan bahwa dalam Kamus Besar Bahasa Indonesia, sejahtera ialah kata benda yang dapat diartikan nasib baik, kesehatan, kebahagiaan, dan 
Wardani, et al/Jurnal Ekonomi Syariah Teori dan Terapan Vol. 6 No. 7 Juli 2019: 1450-1461; KESEJAHTERAAN PETANI PENGGARAP SAWAH PADA PENERAPAN AKAD MUZARA'AH DENGAN PENDEKATAN MAQASHID SYARI'AH DI TULUNGAGUNG

kemakmuran. Berdasarkan istilah umum, sejahtera adalah suatu kondisi yang menunjuk pada keadaan yang baik, makmur, sehat, dan damai.

Kesejahteraan menurut Nasikun (1993) dapat dirumuskan sebagai padanan makna dari konsep martabat manusia yang dapat dilihat dari beberapa indikator yaitu rasa aman (security), kesejahteraan (welfare), kebebasan (freedom), dan jati diri (identity). Konsep kesejahteraan menurut Todaro (2003) bahwa kesejahteraan masyarakat menengah kebawah dapat direpresentasikan dari tingkat hidup masyarakat. Tingkat hidup masyarakat ditandai dengan terentaskannya dari kemiskinan, tingkat kesehatan yang lebih baik, perolehan tingkat pendidikan yang lebih tinggi, dan tingkat produktivitas masyarakat.

Kesejahteraan dalam pandangan islam tentu saja berbeda secara mendasar dengan kesejahteraan dalam ekonomi konvensional. Kesejahteraan dalam ekonomi konvensional hanya menekankan pada kesejahteraan material saja, dengan mengabaikan kesejahteraan spiritual dan moral. Sedangkan dalam pandangan islam, bertujuan mencapai kesejahteraan manusia secara menyeluruh, baik kesejahteraan material, spiritual, maupun moral.

Anto (2003:7) menjelaskan bahwa tujuan utama ekonomi islam adalah merealisasikan tujuan manusia untuk mencapai kebahagiaan dunia dan akhirat (falah), serta kehidupan yang baik dan terhormat (al-hayah al-tayyibah). Kesejahteraan merupakan tujuan dari ajaran islam dalam bidang ekonomi. Kesejahteraan merupakan bagian dari rahmatan lil 'alamin yang diajarkan oleh agama islam. Namun kesejahteraan yang dimaksudkan dalam Al-qur'an bukanlah tanpa syarat untuk mendapatkannya. Kesejahteraan akan diberikan oleh Allah SWT jika manusia melaksanakan apa yang diperintahkannya dan menjauhi apa yang dilarangnya (Syamsuddien, 1994:66-68).

P3El (2008:4) menjelaskan bahwa kesejahteraan menurut islam mencakup dua pengertian antara lain:

a. Kesejahteraan di dunia dan akhirat. Manusia tidak hanya hidup di dunia melainkan juga hidup di alam setelah kematian atau disebut dengan akhirat. Kecukupan materi dunia ditunjukkan dalam rangka untuk memperoleh kecukupan di akhirat. Jika kondisi ideal ini tidak dapat tercapai maka kesejahteraan di akhirat akan lebih diutamakan karena merupakan sesuatu yang kekal dan bernilai disbanding di dunia.

b. Kesejahteraan holistic dan seimbang. Kecukupan materi yang didukung oleh terpenuhinya kebutuhan spiritual serta mencakup individu dan sosial. Sosok manusia terdiri atas unsur fisik dan jiwa, karena itu kebahagiaan haruslah menyeluruh dan seimbang diantara keduanya. 
Wardani, et al/Jurnal Ekonomi Syariah Teori dan Terapan Vol. 6 No. 7 Juli 2019: 1450-1461; KESEJAHTERAAN PETANI PENGGARAP SAWAH PADA PENERAPAN AKAD MUZARA'AH DENGAN PENDEKATAN MAQASHID SYARI'AH DI TULUNGAGUNG

Indikator Kesejahteraan Petani dalam Berbagai Pandangan. Sudana dkk., (dalam Burhansyah dan Melia P, 2010:308) menyebutkan sedikitnya ada lima aspek yang dapat menunjukkan indikator kesejahteraan petani:

a. Perkembangan Struktur Pendapatan.

b. Perkembangan Pengeluaran Untuk Pangan.

c. Perkembangan Nilai Tukar Petani (NTP).

d. Perkembangan ketahanan pangan ditingkat rumah tangga petani.

e. Daya beli rumah tangga petani.

Penjelasan mengenai kelima indikator tersebut dapat dijelaskan sebagai berikut.Kelima indikator diatas merupakan ukuran kesejahteraan yang diukur lebih banyak didasarkan pendekatan bidang ilmu pertanian dimana masing-masing indikator saling berkaitan. Struktur pendapatan diartikan Setiawan (2008:15) sebagai balas jasa yang diterima seseorang sebagai imbalan atas pemberian factor-faktor produksi kedalam proses produksi. Hal ini menyangkut pendapatan yang berasal dari kegiatan usaha tani, kegiatan diluar usaha tani, dan kegiatan diluar pertanian seperti perdagangan dan lain sebagainya.

Indikator yang digunakan dalam pengukuran kesejahteraan petani yakni Nilai Tukar Petani (NTP) dan daya beli rumah tangga dimana keduanya juga saling berkaitan. BPS (2008) mengartikan NTP sebagai rasio antara indeks harga yang diterima dengan indeks harga yang dibayar oleh petani sekaligus sebagai ukuran daya beli petani. Semakin tinggi NTP menunjukkan semakin kuat kemampuan/daya beli petani yang menggambarkan semakin sejahtera tingkat kehidupan petani (BPS,2008).

1. Indikator Kesejahteraan Dalam Islam Indikator sejahtera menurut Islam adalah terpenuhinya kebutuhan fisik dari rizqi yang halal,hidup sehat baik jasmani maupun rohani, keberkahan rezeki yang diterima, keluarga sakinah mawaddah wa rahmah, rasa cinta kasih sesama, ridha dan qana'ah dengan apa yang diberikan Allah kepadanya serta merasa bahagia. Dengan demikian maka kesejahteraan bukan hanya diukur dari terpenuhinya kebutuhan fisik dan materi saja,melainkan juga terpenuhinya kebutuhan spiritual.

Zadjuli (2006) juga menjelaskan bahwa indikator kesejahteraan yang diturunkan dari nilai-nilai Al-Qur'an (Maqashid Syari'ah) adalah sebagai bentuk:

a. Memelihara nilai-nilai agama dan melaksanakan ajaran-ajarannya (hifzud-dien) dalam bekerja untuk mencapai ekonomi keluarga yang sakinah, mawaddah, wa rahmah penuh ketentraman dan ketenangan (hifzun-nabal).

b. Menumbuhkan nilai-nilai yang mampu memelihara keselamatan jiwa dalam rumah tangga atau masyarakat (hifzun-nafs) yang ditandai oleh angka kesakitan 
Wardani, et al/Jurnal Ekonomi Syariah Teori dan Terapan Vol. 6 No. 7 Juli 2019: 1450-1461; KESEJAHTERAAN PETANI PENGGARAP SAWAH PADA PENERAPAN AKAD MUZARA'AH DENGAN PENDEKATAN MAQASHID SYARI'AH DI TULUNGAGUNG

dalam rumah tangga atau masyarakat.

c. Menegakkan nilai-nilai yang menjamin pemikiran manusia yang jenius (hifz-'aql) yang ditandai oleh terpenuhinya kewajiban menuntut ilmu untuk mendapatkan pengetahuan dan pengalaman yang dapat dijadikan sandaran dalam mencari kehidupan yang dirihoi Allah SWT.

d. Membangun nilai-nilai yang mampu menjamin pengembangan ekonomi keluarga atau masyarakat yang saling menguntungkan (hifz-maal) yang ditandai oleh terpenuhinya kebutuhan hidup rumah tangga yang diperoleh dari aktivitas ekonomi yang di ridhoi Allah (rizqi halalan thayyibah).

2. Akad Kerjasama dalam Bidang Pertanian

a. Musaqah

Menurut Abdurrahman al-Jaziri (2003:20) dalam Ghazaly,dkk (2010: 109) musaqah ialah akad untuk pemeliharaan pohon kurma, tanaman (pertanian), dan yang lainnya dengan syarat-syarat tertentu. Menurut Ibn 'Abidin dalam Nasrun Haroen (2007: 275), musaqah ialah penyerahan sebidang kebun pada petani untuk digarap dan dirawat dengan ketentuan bahwa petani mendapatkan bagian dari hasil kebun itu.

b. Mukhabarah
Munawir (1997: 319) mengemukakan bahwa kata Mukhabarah secara bahasa mempunyai pengertian tanah gembur atau lunak. Mukhabarah adalah bentuk kerjasama antara pemilik sawah dengan petani penggarap dengan perjanjian bahwa hasilnya akan dibagi menurut kesepakatan bersama, sedangkan biaya dan benihnya dari petani penggarap (Ghazaly dkk, 2010: 117).

c. Muzaraah

Antonio (2001: 82) menjelaskan bahwa muzara'ah adalah kerjasama pengolahan pertanian antara pemilik tanah dan penggarap, dimana pemilik lahan memberikan lahan pertanian kepada si penggarap untuk ditanami dan dipelihara dengan imbalan bagian tertentu (presentase) dari hasil panen. Muzara'ah sering diidentifikasikan dengan mukhabarah.Diantara keduanya terdapat sedikit perbedaan sebagai berikut: muzara'ah benih dari pemilik lahan, sedangkan mukhabarah benih dari petani penggarap.Jumhur ulama yang membolehkan akad muzara'ah mengemukakan beberapa rukun yang harus dipenuhi, sehingga akad dianggap sah. (Ghazaly dkk, 2010: 115). Rukun muzara'ah menurut mereka adalah sebagai berikut: 
Wardani, et al/Jurnal Ekonomi Syariah Teori dan Terapan Vol. 6 No. 7 Juli 2019: 1450-1461; KESEJAHTERAAN PETANI PENGGARAP SAWAH PADA PENERAPAN AKAD MUZARA'AH DENGAN PENDEKATAN MAQASHID SYARI'AH DI TULUNGAGUNG

a. Pemilik Iahan.

b. Petani penggarap (pengelola).

c. Objek muzara'ah yaitu manfaat lahan dan hasil kerja petani.

d. ljab dan Kabul

Menurut jumhur ulama, syaratsyarat muzara'ah ada yang berkaitan dengan orang yang berakad, benih yang akan ditanam, lahan yang akan dikerjakan, hasil yang akan dipanen, dan jangka waktu berakad (Hasan, 2004: 276). Syarat-syarat tersebut antara lain:

a. baligh dan berakal

b. benih yang akan ditanam harus jelas dan menghasilkan.

c. Luas lahan pertanian yang disepakati untuk dikerjakan harus jelas.

d. Pembagian hasil kerjasama pertanian harus jelas.

e. Jangka waktu dalam akad kerjasama harus jelas

f. Obyek akad juga harus jelas pemanfaatannya

3. Skema Akad Muzaraah

Antonio (2001: 100) mengemukakan bahwa secara umum, sistem muzara'ah dapat digambarkan dalam skema berikut ini :

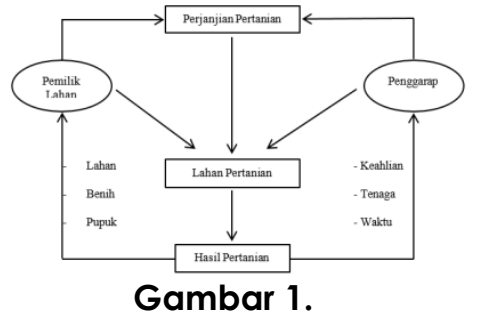

Skema Akad Muzara'ah

Dari skema diatas dapat dijelaskan bahwa akad muzara'ah adalah akad kerjasama (perjanjian) dalam bidang pertanian diantara pemilik lahan dengan petani penggarap. Dimana, pihak pemilik lahan menyediakan lahan pertanian, benih, dan pupuk untuk diolah sedangkan pihak petani penggarap menggunakan keahlian, tenaga dan waktunya untuk mengolah lahan pertanian. Kemudian hasil pertanian dari akad kerjasama tersebut akan dibagi sesuai dengan kesepakatan bersama.

\section{METODE PENELITIAN}

Penelitian ini menggunakan pendekatan kualitatif deskriptif.Menurut Yin (2009:2) pendekatan kualitatif adalah pendekatan dengan menggunakan data yang berupa kalimat tertulis atau lisan, peristiwa-peristiwa, pengetahuan atau proyek studi yang bersifat deskriptif.Secara harfiah, metode kualitatif deskriptif adalah metode penelitian untuk membuat gambaran mengenai situasi atau kejadian.Peneliti tidak hanya menggambarkan fenomena yang ada, akan tetapi juga menjelaskan hubungan dan makna serta implikasi dari masalah yang ingin dipecahkan. Pendekatan kualitatif dengan metode deskriptif adalah mengkomunikasikan realitas yang ada dengan berdasarkan sudut pandang dari informan.

Penelitian kualitatif memiliki beberapa strategi pendekatan, yaitu: Studi Kasus, Etnografi, Fenomenologi, Etnometodologi, dan Grounded Theory. Dari beberapa strategi pendekatan yang ada, Peneliti menggunakan strategi studi 
Wardani, et al/Jurnal Ekonomi Syariah Teori dan Terapan Vol. 6 No. 7 Juli 2019: 1450-1461; KESEJAHTERAAN PETANI PENGGARAP SAWAH PADA PENERAPAN AKAD MUZARA'AH DENGAN PENDEKATAN MAQASHID SYARI'AH DI TULUNGAGUNG

kasus untuk menjawab pertanyaan pada rumusan masalah.

Berdasarkan sumbernya terdapat dua jenis sumber data yang dapat dikumpulkan oleh peneliti, yaitu :

a. Data primer, yaitu data yang diperoleh peneliti secara langsung dari informan melalui wawancara dan observasi. Key informan yaitu ketua kelompok tani di Desa Sodo dan informan nya yaitu para petani penggarap sawah.

b. Data sekunder yaitu data yang berunsur non-manusia sebagai data pendukung penelitian, data yang dimaksud adalah data yang bersifat dokumen.

Teknik penentuan informan dalam penelitian ini menggunakan teknik purposive sampling. Menurut Sugiyono (2012:218), teknik purposive adalah teknik pengambilan sumber data dengan pertimbangan tertentu. Pertimbangan tertentu ini, misalnya informan tersebut dianggap memahami informasi sehingga akan memudahkan peneliti menjelajahi obyek atau situasi sosial yang diteliti.

Yin (2013: 103) menjelaskan bahwa, penelitian kualitatif dengan strategi studi kasus bisa didasarkan atas enam sumber bukti yang dapat dijadikan fokus bagi pengumpulan data, adalah: dokumen, rekaman arsip, wawancara, observasi langsung, observasi pemasaran, serta perangkat fisik. Adapun prosedur pengumpulan data yang digunakan peneliti dalam penelitian ini adalah sebagai berikut:

1. Persiapan Awal

Persiapan awal yang dilakukan adalah peneliti mengurus perizinan penelitian di bagian akademik Fakultas Ekonomi dan Bisnis Universitas Airlangga untuk mendapatkan surat pengantar penelitian resmi. Setelah mendapatkan surat pengantar penelitian, peneliti kemudian melakukan peninjauan awal dengan mendatangi Desa Sodo Kecamatan Pakel Kabupaten Tulungagung dan mengutarakan maksud dan tujuannya. Survei pendahuluan berupa observasi dan peninjauan awal juga dilakukan dengan mendatangi masyarakat Desa Sodo Kecamatan Pakel Kabupaten Tulungagung yang bermatapencaharian sebagai petani.Observasi dilakukan secara terus terang.

2. Penelitian Lapangan

Pada tahap penelitian lapangan, wawancara merupakan sumber analisis data, selain itu wawancara menjadi perangkat penting karena dalam penelitian kualitatif penelitian lebih berupa kata-kata. Setelah melakukan persiapan awal yang berupa pengurusan perizinan baik melalui bagian akademik Fakultas Ekonomi dan Bisnis Universitas Airlangga, kemudian peneliti melakukan wawancara mendalam dan terstruktur kepada para informan dengan mengajukan pertanyaan-pertanyaan pokok penelitian yang sudah disusun 
Wardani, et al/Jurnal Ekonomi Syariah Teori dan Terapan Vol. 6 No. 7 Juli 2019: 1450-1461; KESEJAHTERAAN PETANI PENGGARAP SAWAH PADA PENERAPAN AKAD MUZARA'AH DENGAN PENDEKATAN MAQASHID SYARI'AH DI TULUNGAGUNG

sebelumnya.Wawancara ini dilakukan

untuk mengetahui bagaimana

kesejahteraan petani penggarap sawah di Desa Sodo Kecamatan Pakel Kabupaten Tulungagung setelah menerapkan akad Muzara'ah ditinjau dari Maqashid Syari'ah.

3. Saat Pengumpulan Data

Peneliti mengumpulkan data primer yang diperoleh dari hasil wawancara dengan informan yang sudah ditentukan yang dilakukan secara terbuka.Informan tersebut adalah dari para petani khususnya petani penggarap sawah di Desa Sodo Kecamatan Pakel Kabupaten Tulungagung terkait dengan akad kerjasama muzara'ah yang dilakukan serta untuk mengetahui implikasi dari akad kerjasama tersebut dari segi kesejahteraan dengan pendekatan maqashid syari'ah.Materi wawancara yang dipersiapkan adalah pertanyaan yang dapat berkembang disesuaikan dengan informan yang ditemui.Wawancara berakhir apabila informasi yang dibutuhkan telah didapatkan dan tidak ada informasi baru lagi yang berkaitan dengan topic penelitian. Hasil observasi dan wawancara akan didokumentasikan dengan catatan yang kemudian disarikan oleh peneliti.

\section{HASIL DAN PEMBAHASAN}

\section{Perkembangan Indikator Kesejahteraan para Informan}

Penelitian mengenai kesejahteraan petani penggarap sawah yang melakukan kerjasama pertanian dengan akad muzara'ah di desa Sodo kecamatan Pakel kabupaten Tulungagung telah selesai dilakukan. Hasil penelitian didapat melalui proses pengumpulan data yang dilakukan pada objek dan subjek penelitian. Pengumpulan data tersebut disesuaikan dengan indikator-indikator yang menjadi tolak ukur keberhasilan petani penggarap sawah dalam mencapai kesejahteraan. Indikator yang digunakan untuk mengukur kesejahteraan dalam penelitian ini adalah Maqashid Syari'ah yaitu terdiri dari Agama, Jiwa, Akal, Keturunan, dan Harta.

Alasan penggunaan Maqashid Syari'ah dalam penelitian ini dikarenakan lebih lengkap dibandingkan dengan indikator kesejahteraan petani dalam perspektif konvensional. Perbedaannya, indikator kesejahteraan petani secara konvensional hanya mencakup ukuran duniawi, materi, dan jasadiyah semata. Sedangkan pengukuran kesejahteraan petani dengan Maqashid Syari'ah tidak hanya mencakup duniawi, materi, dan jasadiyah saja namun juga mencakup non-materi, akhirat, dan ruhaniyah.

Perkembangan

indikator kesejahteraan para informan dari hasil wawancara dan observasi adalah sebagai berikut:

a. Informan 1

Berdasarkan Tabel 1 dapat dilihat bahwa setelah melakukan kerjasama pertanian dengan akad muzara'ah, informan 1 mengalami peningkatan kesejahteraan 
Wardani, et al/Jurnal Ekonomi Syariah Teori dan Terapan Vol. 6 No. 7 Juli 2019: 1450-1461; KESEJAHTERAAN PETANI PENGGARAP SAWAH PADA PENERAPAN AKAD MUZARA'AH DENGAN PENDEKATAN MAQASHID SYARI'AH DI TULUNGAGUNG

pada 4 indikator kesejahteraan

berdasarkan maqashid syari'ah yaitu agama, akal, keturunan, dan harta.

Tabel 1.

\section{Perkembangan Indikator Kesejahteraan} Informan 1

\begin{tabular}{|c|c|c|c|}
\hline Indikator & $\begin{array}{l}\text { Sebelum ikut } \\
\text { Muzara'ah }\end{array}$ & Setelah ikut Muzara'ah & Keterangan \\
\hline Agama & $\begin{array}{l}\text { 1. Shalat nutin } 5 \text { waltu } \\
\text { 2. Zaksat Fitrah }\end{array}$ & $\begin{array}{l}\text { 1. Shalat rutin } 5 \text { waktu } \\
\text { 2. Zsksat Fitrah } \\
\text { 3. Infaq } \\
\text { 4. Shadaqah } \\
\text { 5. Pengetahuan tentang } \\
\text { kerjasama Mizara'ah } \\
\text { disyari'atkan oleh } \\
\text { Islam }\end{array}$ & Meningkat \\
\hline Jiwa & $\begin{array}{lr}\text { Mendapat fasilitas } \\
\text { kesehatan dari } \\
\text { pemerintah (KIS) }\end{array}$ & $\begin{array}{lr}\text { Mendapat } & \text { fasilitas } \\
\text { kesehatan } & \text { dari } \\
\text { pemerintah (KIS) } & \\
\end{array}$ & Tetap \\
\hline Akal & $\begin{array}{lr}\text { Pengetahuan } & \text { tentang } \\
\text { pertanian } & \text { masih } \\
\text { terbatas } & \end{array}$ & $\begin{array}{lr}\text { Menambah } & \text { ilmu } \\
\text { pengetahuan } & \text { tentang } \\
\text { pertanian } & \text { melalui } \\
\text { pelatihan } & \text { dan } \\
\text { pendampingan } & \text { setiag } \\
\text { sebulan seksli } & \text { oleh } \\
\text { Poltan. } & \\
\end{array}$ & Meningkst \\
\hline Keturunan & $\begin{array}{l}\text { Dapat membiayai } \\
\text { selkolah anak }\end{array}$ & $\begin{array}{l}\text { 1. Dapat membiayai } \\
\text { selkolah anak: } \\
\text { 2. Dut bimbingan belajar }\end{array}$ & Meningkat \\
\hline Harta & $\begin{array}{l}\text { 1. Memiliki } \\
\text { tanggungan hutang } \\
\text { 2. Dinding dapur } \\
\text { masih separuh dari } \\
\text { anyaman bambu } \\
\text { 3. Pendapatan tidak } \\
\text { menentu tisp } \\
\text { bulannya }\end{array}$ & $\begin{array}{l}\text { 1. Dapat melunasi } \\
\text { sebagian hutang } \\
\text { 2. Membenahi dinding } \\
\text { dapur dengan tembol } \\
\text { utuh } \\
\text { 3. Pendspatan Rp } \\
6.000 .000 / \text { Panen atsu } \\
\text { Rp. } 1.500 .000 / \text { bulan }\end{array}$ & Meningkat \\
\hline
\end{tabular}

Sumber: Hasil Pengolahan Data, 2018

b. Informan 2

Tabel 2.

Perkembangan indicator kesejahteraan informan 2

\begin{tabular}{|c|c|c|c|}
\hline Indikator & $\begin{array}{l}\text { Sebelum ikut } \\
\text { Muzara'ah }\end{array}$ & Setelah ikut Muzara'ah & Keterangan \\
\hline Agama & $\begin{array}{l}\text { 1. Shalat rutin } 5 \text { walktu } \\
\text { 2. Zakst Fitrah } \\
\text { 3. Infaq } \\
\text { 4. Shadaqah }\end{array}$ & $\begin{array}{l}\text { 1. Shalat rutin } 5 \text { waktu } \\
\text { 2. Zalsat Fitrah } \\
\text { 3. Infaq } \\
\text { 4. Shadaqah } \\
\text { 5. Pengetahuan tentang } \\
\text { kerjasama Mizara'ah } \\
\text { disyari'atkan oleh } \\
\text { Islam }\end{array}$ & Meningkat \\
\hline Jiwa & $\begin{array}{l}\text { Membeli obat tolso } \\
\text { atsu Berobat ke bidan/ } \\
\text { mantri ketika salkit }\end{array}$ & $\begin{array}{l}\text { Membeli obat tolko atan } \\
\text { Berobat ke bidan/ mantri } \\
\text { ketika salkit }\end{array}$ & Tetap \\
\hline Akal & $\begin{array}{|lr|}\text { Pengetahuan } & \text { tentang } \\
\text { pertanian } & \text { masih } \\
\text { terbatas } & \end{array}$ & $\begin{array}{lr}\text { Menambah } & \text { ilmu } \\
\text { pengetahuan } & \text { tentang } \\
\text { pertanian } & \text { melalui } \\
\text { pelatihan } & \text { din } \\
\text { pendampingan } & \text { setiag } \\
\text { sebulan selsali } & \text { oleh } \\
\text { Poltan. } & \end{array}$ & Meningkst \\
\hline Kefurunan & $\begin{array}{l}\text { Biaya menyelkolahksan } \\
\text { anak masih dari } \\
\text { hutang }\end{array}$ & $\begin{array}{l}\text { Dapat membiayai } \\
\text { selkolah anak: }\end{array}$ & Meningkat \\
\hline Harta & $\begin{array}{|lrr|}\text { Pendispatan } & < & \mathrm{Rp} \\
600.000 & & \text { tiap } \\
\text { bulannya. } & & \\
\end{array}$ & $\begin{array}{l}\text { Pendispatan Rp } 4.500 .000 \\
\text { Panen atsu } \quad \text { Rp. } \\
1.125 .000 / \text { bulan }\end{array}$ & Meningkat \\
\hline
\end{tabular}

Sumber: hasil pengolahan data, 2018

Berdasarkan Tabel dapat dilihat bahwa setelah melakukan kerjasama pertanian dengan akad muzara'ah, informan 2 mengalami peningkatan kesejahteraan pada 4 indikator kesejahteraan berdasarkan maqashid syari'ah yaitu indikator agama, akal, keturunan, dan harta.

c. Informan 3

Tabel 3.

Perkembangan indicator kesejahteraan informan 3

\begin{tabular}{|c|c|c|c|}
\hline Indikator & $\begin{array}{l}\text { Sebelum ikut } \\
\text { Muzara'ah }\end{array}$ & Setelah ikut Muzara'ah & Keterangan \\
\hline Agama & $\begin{array}{l}\text { 1. Shalat rutin } 5 \text { walktu } \\
\text { 2. Zakat Fitrah }\end{array}$ & $\begin{array}{l}\text { 1. Shalat rutin } 5 \text { waltu } \\
\text { 2. Zalsat Fitrah } \\
\text { 3. Infag } \\
\text { 4. Shadiagah } \\
\text { 5. Pengetahuan tentang } \\
\text { kerjasams Mizara'ah } \\
\text { disyari'atkan oleh } \\
\text { Islam }\end{array}$ & Meningkat \\
\hline Jiwa & $\begin{array}{l}\text { Membeli obat tolko/ } \\
\text { warung }\end{array}$ & \begin{tabular}{|l} 
Berobat ke dokter atsu ke \\
Puskesmas
\end{tabular} & Meningkat \\
\hline Akal & $\begin{array}{lr}\text { Pengetahuan } & \text { tentang } \\
\text { pertanian } & \text { masih } \\
\text { terbatas } & \end{array}$ & 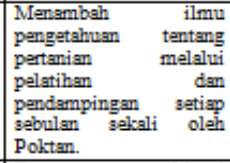 & Meningkst \\
\hline Keturunan & $\begin{array}{lr}\text { Biaya } & \text { untuk } \\
\text { menyekolahkan anak } \\
\text { minim selkali }\end{array}$ & $\begin{array}{l}\text { Dapat membiayai } \\
\text { sekolah anak dengan } \\
\text { hasil dari muzara'ah }\end{array}$ & Meningkat \\
\hline Harta & $\begin{array}{l}\text { Pendapatan tidak } \\
\text { menentu sehingga } \\
\text { seringkali berhutang } \\
\text { kepada tetangga }\end{array}$ & $\begin{array}{l}\text { 1. Dapat melunasi hutang } \\
\text { 2. Dspat membeli } \\
\text { perabotan rumah } \\
\text { seperti almari den } \\
\text { ranjang tidur } \\
\text { 3. Pendapstan Rp Rp } \\
5.250 .000 . \text { Panen atan } \\
\text { seksitar Rp. } 1.300 .000 \\
\text { bulan }\end{array}$ & Meningkat \\
\hline
\end{tabular}

Sumber: hasil pengolahan data, 2018

Berdasarkan Tabel dapat dilihat bahwa setelah melakukan kerjasama pertanian dengan akad muzara'ah, informan 3 mengalami peningkatan kesejahteraan pada kelima indikator kesejahteraan berdasarkan maqashid syari'ah yaitu indikator agama, jiwa, akal, keturunan, dan harta.

d. Informan 4

Berdasarkan Tabel dapat dilihat bahwa setelah melakukan kerjasama pertanian dengan akad muzara'ah, informan 4 mengalami peningkatan kesejahteraan pada 4 indikator kesejahteraan berdasarkan maqashid syari'ah yaitu indikator agama, jiwa, akal, dan harta. 
Wardani, et al/Jurnal Ekonomi Syariah Teori dan Terapan Vol. 6 No. 7 Juli 2019: 1450-1461; KESEJAHTERAAN PETANI PENGGARAP SAWAH PADA PENERAPAN AKAD MUZARA'AH DENGAN PENDEKATAN MAQASHID SYARI'AH DI TULUNGAGUNG

Tabel 4.

perkembangan indicator kesejahteraan informan 4

\begin{tabular}{|c|c|c|c|}
\hline Indikator & $\begin{array}{l}\text { Sebelum ikut } \\
\text { Muzara'ah }\end{array}$ & Setelah ikut Muzara'ah & Keterangan \\
\hline Agama & $\begin{array}{l}\text { 1. Shalat rutin } 5 \text { waktu } \\
\text { 2. Zakat Fitrah }\end{array}$ & $\begin{array}{l}\text { 1. Shalat nutin } 5 \text { waktu } \\
\text { 2. Zalkat Fitrah } \\
\text { 3. Infag } \\
\text { 4. Shadisqah } \\
\text { 5. Pengetahuan tentang } \\
\text { kerjasama Mizava'ah } \\
\text { disyari'stlkan oleh } \\
\text { Islam }\end{array}$ & Meningkat \\
\hline Jiwa & Berobat ke Puskesmas & \begin{tabular}{lr|} 
1. Berobat ke Puskesmas \\
2. Berobat ke RS dengan \\
memalkai & BPJS \\
kesehatan & pribadi \\
(Kelas 3).
\end{tabular} & Meningkat \\
\hline Akal & $\begin{array}{l}\text { Pengetahuan tentang } \\
\text { pertanian } \\
\text { terbatas }\end{array}$ & 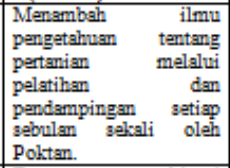 & Meningkat \\
\hline Keturunan & $\begin{array}{l}\text { Dapat membiayai } \\
\text { sekolah anak }\end{array}$ & $\begin{array}{l}\text { Dapat membiayai } \\
\text { selkolah anak: }\end{array}$ & Tetap \\
\hline Harta & $\begin{array}{l}\text { Pendapatan }<\text { Rp } \\
1.000 .000\end{array}$ & 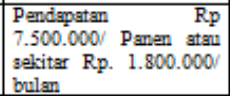 & Meningkat \\
\hline
\end{tabular}

Sumber: hasil pengolahan data, 2018

e. Informan 5

Tabel 5.

perkembangan indicator kesejahteraan informan 5

\begin{tabular}{|c|c|c|c|}
\hline Indikator & $\begin{array}{l}\text { Sebelum ikut } \\
\text { Muzara'ah }\end{array}$ & Setelah ikut Muzara'ah & Keterangan \\
\hline Agama & $\begin{array}{l}\text { 1. Shalat rutin } 5 \text { waltu } \\
\text { 2. Zalkat Fitrah }\end{array}$ & $\begin{array}{l}\text { 1. Shalat rutin } 5 \text { waktu } \\
\text { 2. Zaksat Fitrah } \\
\text { 3. Infag } \\
\text { 4. Shadagah } \\
\end{array}$ & Meningkat \\
\hline Jiwa & $\begin{array}{l}\text { Membeli obat toko } \\
\text { warung }\end{array}$ & Berobat ke Puskesmas & Meningkat \\
\hline Akal & $\begin{array}{ll}\text { Pengetahuan } & \text { tentang } \\
\text { pertanian } & \text { masih } \\
\text { terbatas } & \end{array}$ & 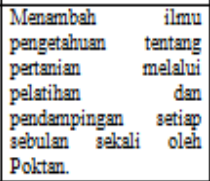 & Meninghast \\
\hline Keturunan & 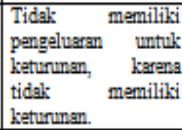 & $\begin{array}{l}\text { Mengadopsi anak dari } \\
\text { saudara serta membiayai } \\
\text { selkolah. }\end{array}$ & Meningkat \\
\hline Harta & $\begin{array}{l}\text { Pendapstan selsitar Rp } \\
500.000 / \text { bulan }\end{array}$ & $\begin{array}{l}\text { Pendspatan selkitar } \\
3.750 .000 \text { lebih / panen } \\
\text { atgn selkitar Rp. } 950.000 / \\
\text { bulan }\end{array}$ & Meningkat \\
\hline
\end{tabular}

Sumber: hasil pengolahan data, 2018

Berdasarkan Tabel dapat dilihat bahwa setelah melakukan kerjasama pertanian dengan akad muzara'ah, informan 5 mengalami peningkatan kesejahteraan pada semua indikator kesejahteraan berdasarkan maqashid syari'ah yaitu indikator agama, jiwa, akal, keturunan dan harta.

Interpretasi Setiap Indikator Kesejahteraan (Maqashid Syari'ah)
Berdasarkan hasil penelitian yang dilakukan, secara keseluruhan informan petani penggarap sawah mengalami peningkatan kesejahteraan menurut islam dengan terpenuhinya seluruh aspek indikator Maqashid Syari'ah. Jika digambarkan dengan grafik akan terlihat seperti berikut :

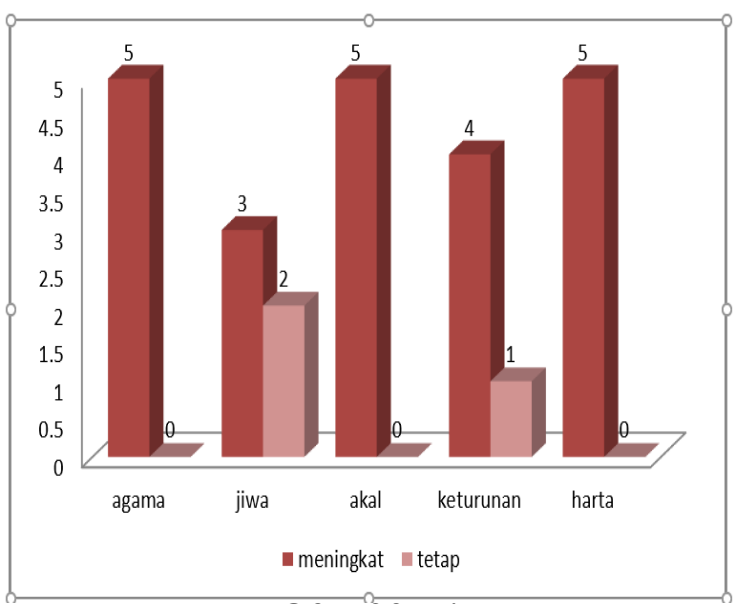

\section{Gambar 2.}

\section{Peningkatan Indikator Kesejahteraan}

\section{Petani Penggarap Sawah}

Berdasarkan gambar diatas dapat dilihat bahwa pada Indikator Agama, 5 informan petani penggarap sawah mengalami peningkatan. Pada indikator Jiwa, 3 informan petani penggarap sawah mengalami peningkatan sedangkan 2 lainnya dalam kondisi tetap. Pada indikator Akal, 5 informan petani penggarap sawah mengalami peningkatan. Pada indikator Keturunan, 4 informan petani penggarap sawah mengalami peningkatan sedangkan 1 lainnya dalam kondisi tetap. Dan yang terakhir pada indikator Harta, kelima informan petani penggarap sawah mengalami peningkatan kesejahteraan. 
Wardani, et al/Jurnal Ekonomi Syariah Teori dan Terapan Vol. 6 No. 7 Juli 2019: 1450-1461; KESEJAHTERAAN PETANI PENGGARAP SAWAH PADA PENERAPAN AKAD MUZARA'AH DENGAN PENDEKATAN MAQASHID SYARI'AH DI TULUNGAGUNG

\section{KESIMPULAN DAN SARAN}

\section{Kesimpulan}

Berdasarkan analisis dan pembahasan yang telah dijelaskan dalam bab sebelumnya bahwa kerjasama pertanian yang dilakukan oleh petani penggarap sawah dan petani pemilik sawah menggunakan akad muzara'ah dengan pendekatan maqashid syari'ah yang diadakan oleh kelompok tani "Krido Tani" di Desa Sodo Kecamatan Pakel Kabupaten Tulungagung dapat meningkatkan kesejahteraan petani penggarap sawah. Kerjasama tersebut membawa dampak positif bagi kehidupan sehari-hari dan membantu meningkatkan perkonomian kelima petani penggarap sawah.

Kesimpulan yang dapat diambil dari hasil penelitian ini yaitu;

1. Hampir semua petani penggarap sawah yang melakukan kerjasama pertanian dengan akad muzara'ah mengalami peningkatan kesejahteraan di seluruh aspek indikator Maqashid Syari'ah.

2. Terdapat petani penggarap sawah yang hanya beberapa aspek indikator saja yang terpenuhi sehingga dalam kondisi tetap atau tidak mengalami perubahan.

3. Pada indikator harta, pendapatan yang diperoleh para petani penggarap sawah dari kerjasama muzara'ah jumlahnya beragam tergantung dengan jumlah lahan sawah yang dikerjakan. Semakin luas lahan sawah yang dikerjakan, maka semakin banyak pendapatan yang diperoleh.

4. Meskipun peningkatan pendapatan tersebut tidak naik secara signifikan, namun kelima informan merasakan adanya perubahan kondisi kesejahteraan yang lebih baik dibandingkan dengan sebelumnya.

Maka dapat dilihat dari hasil penelitian diatas, bahwa petani penggarap sawah setelah melakukan kerjasama pertanian dengan akad muzara'ah dapat mengalami perubahan kondisi kesejahteraan dari sebelumnya meskipun peningkatannya tidak terlalu signifikan.

\section{Saran}

Berikut adalah beberapa saran yang diharapkan dalam penelitian ini, yaitu:

1. Diharapkan dengan adanya hasil penelitian ini, kelompok tani "Krido Tani" yang mengadakan kerjasama pertanian dengan akad muzara'ah untuk para petani penggarap sawah menjadi tahu hasil dari kerjasama muzara'ah yang telah diselenggarakan selama ini dan menjadikan hasil penelitian ini sebagai bahan evaluasi untuk kedepannya.

2. Diharapkan para petani penggarap sawah yang melakukan akad kerjasama muzara'ah lebih giat lagi dalam bekerja sehingga kondisi kesejahteraan mereka terus membaik.

3. Diharapkan para petani penggarap sawah muzara'ah mengajak petani 
Wardani, et al/Jurnal Ekonomi Syariah Teori dan Terapan Vol. 6 No. 7 Juli 2019: 1450-1461; KESEJAHTERAAN PETANI PENGGARAP SAWAH PADA PENERAPAN AKAD MUZARA'AH DENGAN PENDEKATAN MAQASHID SYARI'AH DI TULUNGAGUNG

kurang mampu lainnya yang belum ikut kerjasama muzara'ah untuk bergabung dalam kerjasama pertanian akad muzara'ah sehingga dapat merubah kondisi kesejahteraan mereka.

\section{DAFTAR PUSTAKA}

Anto, M.B. Hendrie. 2003. Pengantar ekonomika Mikro Islami. Yogyakarta: Ekonisia.

Antonio, Muhammad Syafi'i. 2001. Bank Syari'ah dari Teori ke Praktik. Jakarta: Gema Insani.

Biro Pusat Statistik (BPS). 2008. Perkembangan Nilai Tukar Petani dan Harga Produsen Gabah, (online),

(www.bps.go.id/getfile.php?news= 319) diakses 17 Agustus 2017

Burhansyah, Rusli dan Melia P. 2010.Kinerja Usaha Tani Padi dan Indikator Kesejahteraan Petani di Kubu Raya Kalimantan Barat, (Online), (www.pse.litbang.deptan.go.id)/in d/pdffiles/Pros_MP_15_2010.pdf) diakses 17 Agustus 2017

Ghazaly, Abdul Rahman, dkk. 2010. Figh Muamalat. Jakarta: Prenada Media Group.

Haroen, Nasrun. 2007. Fiqh Muamalah. Jakarta: Gaya Media Pratama

Hasan, M. Ali. 20004. Berbagai Macam Transaksi dalam Islam (Figh Muamalat). Jakarta: PT. Raja Grafindo Persada.

Heryawan, Ahmad. 2009. "Kesejahteraan dan Ukurannya". (Online). (http://ahmadheryawan.blogspot. co.id/kesejahteraan-danukurannya). Diakses pada 3 februari 2017.

Munawir, Ahmad Warson. 1997. Kamus Indonesia-Arab-Inggris. Surabaya: Pustaka Progresif

Nasikun. 1993. Sistem Sosial Indonesia. Jakarta: Raja Grafindo Persada

Pusat Pengkajian dan Pengembangan Ekonomi Islam (P3EI). 2008. Ekonomi Islam. Jakarta: PT. Raja Grafindo Persada.

Setiawan, Iwan. 2008. Alternatif Pemberdayaan Bagi Peningkatan Kesejahteraan Petani Lahan Kering (Studi Literatur Petani Jagung di Jawa Barat). Skripsi tidak diterbitkan. Bandung. Fakultas Pertanian Universitas Padjajaran.

Sugiyono. 2010. Metode Penelitian Kuantitatif, Kualitatif, dan R\&D. Bandung: Alfabeta.

Syamsuddien, Darsyaf Ibnu. 1994. Darussalam: Prototype Negeri Yang Damai. Surabaya: Media Idaman Press.

Yin, Robert K. 2009.Case Study Research Design and Methods. Fourth Edition. California: sage inc. 